\title{
Pengembangan Model Permainan Tradisional untuk Membangun Karakter pada Siswa SD Kelas Atas
}

\author{
Puput Widodo $^{1}{ }^{*}$, Ria Lumintuarso ${ }^{1}$ \\ ${ }^{1}$ Program Studi Ilmu Keolahragaan, Program Pascasarjana, Universitas Negeri Yogyakarta. Jalan \\ Colombo No. 1, karangmalang, Yogyakarta, 55281, Indonesia \\ * Corresponding Author. Email: puputwidodo72@gmail.com
}

Received: 23 November 2016; Accepted: 3 October 2017

\begin{abstract}
Abstrak
Penelitian ini mengadaptasi penelitian dan pengembangan pendidikan model Borg \& Gall dengan menyederhanakan menjadi 2 tahapan sebagai berikut (1) tahap pra-pengembangan, tahapan ini meliputi (a) kajian literatur dan penelitian relevan dan (b) studi lapangan, (2) tahap pengembangan, tahapan ini meliputi (a) penyusunan draf, (b) validasi ahli, (c) uji coba model skala kecil, (d) uji coba model skala besar, dan (e) produk akhir. Uji coba skala kecil dilakukan terhadap 30 anak kelas atas SDN Aditirto Pejagoan Kebumen, Provinsi Jawa Tengah. Uji coba skala besar dilakukan terhadap 130 anak kelas atas dari SD Negeri 1 Karangpoh, 26 siswa SD Negeri 1 Logede, 22 siswa SD Negeri 4 Pejagoan, 24 siswa SD Negeri 1 Kebulusan, dan 30 siswa SD Negeri 3 Kebulusan Kecamatan Pejagoan, Kabupaten Kebumen, Provinsi Jawa Tengah. Instrumen yang digunakan untuk mengumpulkan data adalah wawancara, kuisioner penilaian karakter permainan tradisional, kuisioner observasi pengembangan permainan tradisional, kuisioner observasi keefektifan model permainan tradisional, kuisioner penilian observasi ahli media, dan kuisioner evaluasi siswa. Hasil penelitian berupa pengembangan model permainan tradisional terdiri dari 3 jenis permainan yaitu: (1) permainan goteng, (2) lari papan/segi empat, dan (3) kasti tangan. Berdasarkan penilaian para ahli materi dan guru penjasorkes dapat disimpulkan bahwa pengembangan model permainan tradisional yang disusun sangat baik dan efektif, sehingga model permainan layak digunakan untuk pembelajaran pendidikan jasmani pada siswa kelas atas.
\end{abstract}

Kata Kunci: Model, permainan tradisional, karakter, pendidikan jasmani, sekolah dasar

\section{Developing Models of Traditional Games to Build Characters of Elementary School Students of Upper Grades}

\begin{abstract}
The study was conducted through two stages by adapting the research and development of educational models Borg \& Gall as follows (1) pre-development stage, this stage include (a) review of relevant literature and research, and (b) field studies, (2) the development stage, this stage include; (a) drafting, (b) validation expert, (c) testing of small-scale models, (d) testing large-scale models, and (e) of the final product.The small-scale tryout was conducted by involving 30 students of upper grades of state elementary schools (SES) of Aditirto, Pejagoan sub-district, Kebumen regency, Central Java porovinsi. The large-scale tryout was conducted by involving 130 students of upper grades of SES 1 of Karangpoh, 26 students of SES 1 of Logede, 22 students of SES 4 of Pejagoan, 24 students of SES 1 of Kebulusan, and 30 students of SES 3 of Kebulusan Pejagoan sub-district, Kebumen regency, Central Java porovinsi. The data collecting instruments were an interview guideline, a questionnaire to assess characters of traditional games, a questionnaire to assess the traditional game development, a questionnaire for the assessment by the media expert, and a questionnaire for the evaluation by students. The results of the study of the development of models of traditional games were three types of games, i.e: (1) goteng game, (2) board/rectangle running, and (3) hand kasti. Based on the assessment by the materials experts and the teachers of physical, sports, and health education, it could be concluded that the developed modals of traditional games were very good and effective so that they were appropriate to be used in the learning physical education for the students of upper grades.
\end{abstract}

Keywords: models, traditional games, characters, phsical education, elementary school 


\section{Jurnal Keolahragaan 5 (2), September 2017 - 184}

Puput Widodo, Ria Lumintuarso

\section{PENDAHULUAN}

Bermain merupakan kegiatan ataupun aktivitas wajib yang dilakukan anak-anak untuk mengenal lingkungan sekitar, bermain juga sering dilakukan orang dewasa untuk melepaskan kejenuhan dan menghilangkan stres. Bermain (play) adalah setiap kegiatan yang dilakukan untuk kesenangan yang ditimbulkannya, tanpa mempertimbangkan hasil akhir. Menurut Suharjana (2011, p. 4) bermain pada hakikatnya merupakan salah satu kebutuhan hidup bagi anak. Dalam kehidupan anak, bermain merupakan latihan-latihan yang dilakukan agar anak menjadi manusia dewasa yang lebih banyak mendapatkan kesempatan untuk melatih potensipotensi yang ada pada dirinya, oleh karena itu bermain tidak dapat dipisahkan dari kehidupan anak itu sendiri.

Menurut Thompson (Sridadi, 2009, p. 47) bermain berarti menyediakan kesepampatan untuk memperoleh pengalaman belajar yang menyenangkan. Adapun keuntungan yang diperoleh dari aktivitas bermain menurut Mutohir (Sridadi, 2009, p. 47) adalah (a) membuang ekstra energi, (b) mengoptimalkan pertumbuhan seluruh bagian tubuh seperti tulang, otot, dan organ-organ, (c) meningkatkan nafsu makan anak, (d) anak belajar mengontrol diri, (e) berkembangnya berbagai ketrampilan yang akan berguna sepanjang hidupnya, (f) meningkatkan gaya kreatifitas, (g) mendapatkan kesempatan belajar untuk bergaul dengan anak lainnya, (j) kesempatan untuk menjadi pihak yang kalah atau yang menang dalam bermain, $(\mathrm{k})$ kesempatan untuk belajar mengikuti aturan-aturan, dan (1) dapat mengembangkan kemampuan intelektual. Dalam bermain, anak-anak selalu berperilaku diatas usia rata-ratanya, diatas perilakunya sehari-hari, dalam bermain anak dianggap 'lebih' dari dirinya sendiri. Selanjutnya dijelaskan terdapat dua ciri utama bermain, yaitu: (1) semua aktivitas representasional menciptakan situasi imajiner yang memungkinkan anak untuk menghadapi keinginan-keinginan yang tidak dapat direalisasikan dalam kehidupan nyata, dan (2) bermain representasional memuat aturanaturan berperilaku yang harus diikuti oleh anak untuk dapat menjalankan adegan bermain (Sujiono \& Sujiono, 2010, p. 34).

Berdasarkan uraian tersebut, dapat disimpulkan bahwa bermain adalah suatu kegiatan yang apabila dilakukan akan menimbulkan perasaan senang, gembira, bahagia, dan secara tidak sadar aktivitas jasmani telah dilakukan.
Selain itu secara psikis seseorang yang telah bermain merasa dirinya fresh kembali dan kejenuhan dan stres juga akan sedikit berkurang. Banyak macam-macam permainan yang mendukung anak-anak dalam tumbuh kembang anak salah satu contohnya permainan tradisional. Menurut Misbach (2006, p. 7), permainan tradisional yang ada di Nusantara ini dapat menstimulasi berbgai aspek perkembangan anak, seperti; (a) Aspek motorik: melatih daya tahan, daya lentur, sensorimotorik, motorik kasar, motorik halus, (b) aspek kognitif: mengembangkan imajinasi, kreativitas, problem solving, strategi, antisipatif, pemahaman kontekstual, (c) aspek emosi: katarsis emosional, mengasah empati, pengendalian diri, (d) aspek bahasa: pemahaman konsep-konsep nilai, (f) Aspek sosial: menjalin relasi, kerja sama, melatih kematangan sosial dengan teman sebaya dan meletakkan pondasi untuk melatih keterampilansosialisasi berlatih peran dengan orang yang lebih dewasa/masyarakat, (g) Aspek spiritual: menyadari keterhubungan dengan sesuatu yang bersifat agung (transcendental), (h) aspek ekologis: memahami pemanfaatan elemen-elemen alam sekitar secara bijaksana, (i) aspek nilainilai moral: menghayati nilai-nilai moral yang diwariskan dari generasi terdahulu kepada generasi selanjutnya. Jika digali lebih dalam, ternyata makna dibalik nilai-nilai permainan tradisional mengandung pesan-pesan moral dengan muatan kearifan local (local wisdom) yang luhur.

\section{Permainan Tradisional}

Menurut Dharmamulja (1992, p. 23) permainan tradisional merupakan hasil budaya yang besar nilainya bagi anak-anak dalam rangka berfantasi, berekreasi, berkreasi, berolahraga yang sekaligus sebagai sarana berlatih untuk hidup bermasyarakat, ketrampilan, kesopanan, serta ketangkasan. Dari penjelasan tentang permainan, permainan merupakan suatu bentuk kegiatan yang terdapat aturan dan peraturan yang sudah ditetapkan dengan suatu sarana dan prasarana yang sudah ada. Menurut Linggar (2010, p. 1) olahraga/permainan tradisional adalah jenis olahraga yang timbul berdasarkan permainan dari masing-masing suku dan etnis di Indonesia. Olahraga/permainan tradisional harus memenuhi dua persyaratan yaitu berupa "olahraga" dan sekaligus juga "tradisional" baik dalam memiliki tradisi yang telah berkembang selama beberapa generasi, maupun dalam arti sesuatu yang terkait dengan 


\section{Jurnal Keolahragaan 5 (2), September 2017 - 185}

Puput Widodo, Ria Lumintuarso

tradisi budaya suatu bangsa secara lebih luas (Ardiwinata, 2006, p. 1). Permainan tradisional anak-anak di Jawa misalnya, dikatakan mengandung nilai-nilai budaya tertentu serta mempunyai fungsi melatih pemainnya melakukan hal-hal yang akan penting nantinya bagi kehidupan mereka di tengah masyarakat, seperti misalnya melatih cakap hitung menghitung, melatih kecakapan berfikir, melatih bandel (tidak cengeng), melatih keberanian, melatih bersikap jujur dan sportif dan sebagainya Tashadi mengungkapkan (Purwaningsih, 2006, p. 27). Menurut K. Dewi, dkk (2013, p.2) tradisional merupakan suatu permainan yang mirip dengan olah raga yakni memiliki aturan main yang memberikan kesenangan, kegembiraan, dan tantangan.

Berdasarkan uraian tersebut dapat disimpulkan bahwa permainan tradisional adalah aktivitas yang dilakukan tanpa paksaan, mendatangkan rasa kegembiraan, dalam suasana yang menyenangkan berdasarkan tradisi masingmasing daerah yang ada di lingkungan, dimainkan dengan menggunakan alat ataupun tidak menggunakan alat, dan dilakukan sesuai/dengan aturan yang sudah disepakati sebelum permainan dimulai, seperti peraturan, lapangan, jumlah pemain, dan lain sebagainya.

\section{Karakter}

Secara umum karakter hanya dapat terjadi ketika dibangun. Pendikan karakter harus diutamakan dan bukan hanya dalam hanya satu pelajaran tetapi harus dilaksanakan seumur hidup. Menurut Megawangi (2004: 95) pendidikan karakter adalah sebuah usaha untuk mendidik anak-anak agar dapat mengambil keputusan dengan bijak dan mempraktikannya dalam kehidupan sehari-hari, sehingga mereka dapat memberikan kontribusi yang positif terhadap lingkungannya. Definisi lain dikemukakan oleh Fakry Gaffar (Kesuma, 2011, p. 5) "sebuah proses transportasi nilai-nilai kehidupan untuk ditumbuh kembangkan dalam kepribadian seseorang sehingga menjadi satu dalam perilaku kehidupan orang tersebut".

Menurut Megawangi (2004, p.95) ada beberapa karakter dasar yang perlu dibangun untuk anak-anak antara lain: kerja sama, kejujuran, disiplin, tanggung jawab, percaya diri, dan toleransi terhadap sesama/peduli sesama. Berdasarkan observasi dalam penelitian ini ada empat nilai karakter yang perlu dibangun pada siswa SD kelas atas antara lain: kerja sama, kejujuran, percaya diri, dan peduli sesama.

\section{Kerja Sama (Cooperative)}

Menurut Nacy Stevenson (Isti dan Touvan, 2013, p.45) kerja sama merupakan sikap yang memahami bahwa kekuatan banyak orang yang bekerja sama akan lebih besar dibandingkan dengan kemampuan individu. Kerja sama merupakan salah satu nilai yang sering dilatih oleh pelatih-pelatih olahraga khususnya olah-raga permainan yang membutuhkan lebih dari seorang pemain. Kerja sama juga merupakan faktor penting dalam mencapai suatu tujuan prestasi

Dari penjelasan di atas dapat disimpulkan bahwa kerja sama merupakan nilai dari sebuah karakter yang mengidentifikasi bahwa kebersamaan lebih unggul dibandingkan dengan individu dalam mencapai tujuan dalam sebuah kelompok. Dalam pendidikan jasmani nilai kerja sama juga sangat dibutuhkan dalam pembelajaran penjas, mengingat pembelajaran penjas sering menggunakan kelompok dalam setiap pembelajarannya. Misalnya: materi permainan bola besar, bola kecil, permainan tradisional, aktivitas luar kelas, dan lain sebagainya.

\section{Kejujuran (Honest)}

Menurut Lusiana (2012, pp. 64-65) kejujuran adalah kesadaran apa yang benar dan tepat dalam peran seseorang, perilaku seseorang, dan satu hubungan. Dengan kejujuran, tidak ada kemunafikan atau kepalsuan yang menciptakan kebingungan dan ketidakpercayaan dalam pikiran dan kehidupan orang lain. Kejujuran membuat untuk kehidupan integritas karena diri dalam dan luar adalah bayangan cermin. Kejujuran adalah berbicara bahwa yang diduga dan untuk itu yang diucapkan. Tidak ada kontradiksi atau perbedaan dalam pikiran, kata, atau tindakan. Integrasi tersebut memberikan kejelasan dan contoh kepada orang lain.

Berdasarkan uraian tersebut, dapat disimpulkan bahwa kejujuran adalah perilaku yang didasarkan pada upaya menjadikan diri sebagai orang yang selalu dapat dipercaya, baik terhadap diri sendiri maupun orang lain.

\section{Percaya Diri (Self-Confident)}

Istilah rasa percaya diri yang berasal dari kata Self-confindence dan pada hakekatnya merupakan ekspresi dari self-worth atau penghargaan seseorang terhadap dirinya sendiri. Secara psikologi kepercayaan diri dapat membantu kognitif seseorang menjadi positif. Menurut Vealey (Weinberg \& Gould, 2007, p.323) 
Puput Widodo, Ria Lumintuarso

kepercayaan diri dalam olahraga adalah membangun kognitif sosial yang lebih kepada sifat bawaan (traitlike) atau lebih (statelike), tergantung pada kondisi dan referensi yang digunakan. Misalnya, kepercayaan dapat berbeda jika melihat keyakinan tentang kompetensi hari ini dibandingkan dengan keyakinan tentang musim yang akan datang. Keyakinan memang sangat dibutuhkan untuk dapat menumbuhkan percaya diri, bahkan seseorang yang sudah mempunyai percaya diri akan surut oleh faktor-faktor tertentu misalkan kesempatan yang kurang, menipis atau bahkan tidak ada kesempatan sama sekali. Rich (2008, p. 29) mengatakan bahwa: "Confidence ebbs and flows like a river. It does not run at high tide all the time. There are some days when you know you can manage whatever comes, and there are others when getting out of bed can seem a momentous step. So too with children. On those more difficult days, it's helpful to be able to think back to a time when something good happened and you managed well and overcame some odds. It provides the strength to keep going on days when confidence is running low".

\section{Peduli Sesama (Caring)}

Menurut Isti \& Taufan (2013, p.44) peduli terhadap sesama merupakan perasaan tertarik atau perasaan sayang untuk orang lain atau sesuatu. Ketika seorang teman memiliki sebuah masalah maka mendengarkan dan memberi saran merupakan contoh dalam sikap ini. Dalam kata lain peduli sesama merupakan sebuah bantuan atau perlakuan yang diberikan dari seseorang kepada orang lain, baik itu tenaga, pikiran, barang, dan kegiatan lainnya. Peduli sesama juga merupakan salah satu faktor penting dalam bersosialisasi. Rich (2008, p. 89) mengatakan bahwa orang hidup tidak hanya seorang diri tetapi membutuhkan orang lain.

\section{Pengembangan Permaian Tradisional}

Adapun permainan tradisional yang akan dikembangkan yaitu kombinasi antara permainan gobak sodor dan bentengan. (1) permainan gobak sodor dan bentengan merupakan permainan kombinasi dua permainan menjadi satu permainan, (2) permainan lari papan/segi empat termasuk permainan tradisional yang membutuhkan alat di sini ditujukan untuk memberikan variasi permainan yang berbeda dalam pembelajaran, dan (3) kasti tangan merupakan permainan tradisional yang dilakukan kerja sama antar teman dalam setiap kelompoknya, permainan ini di butuhkan skill pada setiap pemain yaitu memukul bola yang dilemparkan dengan tangan, lari dan kordasi mata dengan tubuh yang lainnya. Permainan ini diarahkan untuk dapat melatih karakter yang ingin dicapai dalam pembelajaran penjas. Dari ke tiga permainan tersebut diharapkan dapat menumbuhkan karakter (kerja sama, kejujuran, percaya diri, dan peduli sesama). Sesuai pendapat dari Misbach (2006) bahwa permain tradisional dapat menumbuhkan nilai kerja sama, kejujuran, percaya diri, dan peduli sesama.

Tujuan Pengembangan Model Permainan Tradisional

Tujuan dari model pengembangan permainan tradisional yaitu membangun karakter kerja sama, kejujuran, percaya diri, dan peduli sesama siswa SD kelas atas, dan dapat meningkatkan gerak dasar psikomotor sesuai SK dan $\mathrm{KD}$ dalam pembelajaran penjas SD kelas atas.

Tahapan Pelaksanaan Pengembangan Model Permainan Tradisional

Pengembangan model permainan tradisional diterapkan sebagai berikut: (a) sebelum mempraktikan model permainan tradisional, terlebih dahulu dibagikan buku panduan permainan, supaya anak dapat mempelajari pemainan tradisional terlebih dahulu, (b) diperlihatkan tayangan/ video permainan tradisional sebelum mempraktikan, (c) setelah siswa memahami peraturan dan permainan tradisional, siswa dikondisikan di lapangan dan diberi pemanasan sebelum memulai permainan tradisional, (d) setelah siswa melakukan permainan tradisional, siswa diberi pendinginan dan evaluasi setelah melaksanakan permainan.

\section{Model Pengembangan Permainan Tradisional}

Adapun model pengembangan model permainan tradisional dalam penelitian ini antara lain; (a) Permainan Goteng, Permainan kombinasi ini peneliti memberi nama "goteng" (gobak sodor dan bentengan). Permainan goteng merupakan kombinasi antara permainan gobak sodor dan bentengan dengan memodifikasi peralatan dan aturan permainan, (b) Permainan Lari Papan/Segi Empat, menurut Ardiwinata (2006, p. 28) lari papan/segi empat merupakan permainan yang sering dilombakan pada perayaan Kemerdekaan RI. Bentuk permainan berupa adu kecepatan menempuh suatu jarak tertentu di atas empat buah papan berbentuk segi empat, yang mana setiap habis melangkah 
pemain jarus memindahkan papan yang di belakangnya ke depan sebagai tempat berpijak dan begitu selanjutnya. Permainan ini menuntut kelincahan, keseimbangan dan kecepatan pemainnya. Dalam permainan ini akan dimodifikasi alat dan jumlah pemain. Alat yang digunakan dalam permainan ini bukan papan yang terbuat dari triplek/bahan kayu, melainkan sebuah busa atau kardus berbentuk persegi dengan ukuran $40 \times 40 \mathrm{~cm}$ dengan tujuan dapat mempermudah pemain dan keselamatan pemain dalam melakukan permainan lari papan. Sedangkan jumlah pemain dapat diatur jumlah dalam setiap kelas dan dibagi menjadi beberapa kelompok. Permainan ini merupakan permainan kelompok dan dilakukan secara estafet, dan (c) Kasti Tangan, menurut Husna M (2009, p. 89) kasti merupakan permainan yang dibagi menjadi dua kelompok yang terdiri dari kelompok pemukul dan kelompok jaga. Terdapat beberapa base atau tempat singgah dalam permainannya, alat yang digunakan bola dan tongkat pemukul. Permainan kasti tangan merupakan bentuk sederhana dari permainan kasti yang sebenarnya. Kayu yang digunakan untuk pemukul tidak dipergunakan, melainkan menggunakan tangan peserta. Peserta dibagi menjadi dua regu dan pemenang ditentukan dengan nilai pada waktu yang telah ditentukan.

\section{METODE}

Penelitian ini merupakan penelitian pengembangan (research \& development). Menurut Gall, Gall, \& Borg (2007, p. 570) research \& development adalah sebuah model pengembangan dimana temuan penelitian digunakan untuk merancang produk dan prosedur baru, yang kemudian secara sistematis diuji dilapangan, dievaluasi, dan disempurnakan, sampai memenuhi kriteria tertentu yaitu efektifitas dan berkualitas. Pendapat yang senada dikemukakan oleh Sugiyono (2010, p. 407) penelitian R\&D merupakan metode penelitian yang digunakan untuk menghasilkan produk tertentu dan menguji keefektifan produk tersebut.

Pada penelitian dan pengembangan ini tahapan dimodifikasi (disederhanakan) menjadi 2 tahap yaitu tahap pra-pengembangan dan tahap pengembangan.

\section{Tahap Pra-Pengembangan}

Pada tahap tahap pra-pengembangan berangkat dari permasalahan yang ditemukan dalam pembelajaran aktivitas jasmani SD kelas atas. Pra-pengembangan dilakukan dengan mengindentifikasi permasalahan yang terkait dengan proses pembelajaran, melakukan kajian literatur, kajian penelitian yang relevan dan studi lapangan. Hasil dari pra-pengembangan dijadikan dasar Pengembangan model pembelajaran permainan sederhana khususnya permainan tradisional untuk siswa sekolah dasar kelas atas. Selanjutnya akan dilakukan analisis untuk mengembangkan model yang sesuai dengan kebutuhan yang terdapat di sekolah dasar kelas atas.

\section{Kajian Literatur dan Penelitian Relevan}

Kajian literatur dilakukan terhadap kurikulum pembelajaran, materi pembelajaran permainan sederhana dan karakteristik siswa dari sekolah dasar kelas atas. Kajian terhadap penelitian yang relevan dilakukan terhadap hasil pengembangan atau penerapan model-model pembelajaran di sekolah dasar kelas atas yang telah diteliti. Penelitian yang relevan terkait model pembelajaran, model aktivitas jasmani dan mengenai pembelajaran untuk pencapaian perkembangan karakter siswa.

\section{Studi Lapangan}

Pada tahap studi lapangan dilakukan observasi terhadap guru dan perilaku siswa dalam belajar. Observasi dilakukan untuk memperoleh data terkait pelaksanaan proses pembelajaran di sekolah sekolah dasar kelas atas dan pelaksanaan aktivitas jasmani. Adapun halhal yang diobservasi meliputi model permbelajaran permainan tradisional yang diajarkan guru, metode yang digunakan guru dalam mengajar, kelengkapan guru dalam mengajar, tingkat keaktifan siswa dalam belajar, dan karakter siswa dalam pembelajaran.

\section{Tahap Pengembangan}

Tahap pengembangan dibagi menjadi beberapa langkah-langkah yaitu (a) penyusunan draft model awal pembelajaran, (b) validasi ahli, (c) uji coba skala kecil, (4) uji coba skala besar, dan (e) produk operasioanl terbatas. Adapun penjelasan dari langkah-langkah pada tahap pengembangan sebagai berikut :

\section{Penyusunan Draf Model Awal}

Hasil dari pengembangan berupa draft rancangan awal (prototype) mengenai pengembangan model pembelajaran permainan tradisional untuk siswa sekolah dasar kelas atas. Draft model pembelajaran yang dihasilkan berupa 
desain model pembelajaran dan implementasi. Draft model pengembangan berupa buku panduan selanjutnya dilakukan validasi model dan uji coba model.

\section{Validasi Ahli}

Validasi model merupakan tahapan untuk mengetahui kelayakan dari draft yang telah disusun. Validasi dilakukan dengan menyerahkan draft model kepada para ahli untuk mendapatkan kesahihan instrumen dan draf. Validasi dari para ahli materi, yaitu: (1) pakar pembelajaran pendidikan jasmani, (2) pakar pendidikan jasmani (guru penjas SD) dan (3) pakar ahli media.

\section{Uji Coba Skala Kecil}

Uji coba kecil dilakukan untuk mengetahui tingkat implementasi model yang dikembangkan. Uji coba skala kecil menekankan pada aspek muatan (subtansi isi dan pelaksanaannya) bukan pada hasil (outcomes). Pada uji coba skala kecil dilakukan dengan mengimplementasikan model permainan tradisional yang dilaksanakan satu sekolah yaitu SDN Aditirto, Kec. Pejagoan, Kab. Kebumen yang berjumlah 30 siswa. Guru menjalankan model pembelajaran dengan menggunakan rancangan model permainan yang dikembangakan.

\section{Uji Coba Skala Besar}

Uji coba secara besar dilakukan pada 5 (lima) SD dengan jumlah siswa 130 siswa, terdiri dari 28 siswa SD Negeri 1 Karangpoh, 26 siswa SD Negeri 1 Logede, 22 siswa SD Negeri 4 Pejagoan, 24 siswa SD Negeri 1 Kebulusan, dan 30 siswa SD Negeri 3 Kebulusan pada siswa kelas atas. Setelah dilakukan uji lapangan lebih luas, dilakukan revisi hasil uji kajian produk akhir.

\section{Produk Akhir}

Setelah dilakukan uji coba skala besar, maka dihasilkan model produk akhir. Produk akhir merupakan model permainan tradisional untuk membangun karakter siswa sekolah dasar kelas atas yang sudah dapat implementasikan oleh guru sekolah dasar kelas atas dalam pembelajaran sesungguhnya

\section{Subjek Penilitian}

Subjek dalam penelitian ini merupakan sarana pemakai produk yaitu siswa SD kelas atas. Adapun subjek dalam penelitian ini berjumlah 160 siswa antara lain 30 siswa SDN
Aditirto, 28 siswa SDN 1 Karangpoh, 26 siswa SDN 1 Logede, 22 siswa SDN 4 Pejagoan, 24 siswa SDN 1 Kebulusan, dan 30 siswa SDN 3 Kebulusan Kecamatan Pejagoan, Kabupaten Kebumen, Provinsi Jawa Tengah.

\section{Teknik dan Instrumen Pengumpulan Data}

Instrumen yang digunakan untuk mengumpulkan data berupa instrumen penilaian untuk menilai produk yang telah dikembangkan dari aspek kesesuaian, aspek isi, aspek kemudahan, dan aspek rangsangan terhadap gerak siswa. Selain itu metode pengamatan dilaksanakan untuk menilai/mengetahui karakter yang diinginkan dapat tercapai atau tidak melalui kuisioner penilaian karakter. Instrumen yang digunakan dan dikembangkan dalam penelitian ini meliputi: (a) kuesioner untuk ahli (pendidikan jasmani, dan guru penjas) dan guru untuk menilai draf model pengembangan, (b) lembar pengamatan untuk mengetahui karakter siswa melalui permainan yang dilaksanakan, (c) kuesioner untuk observasi pengembangan model, (d) kuesioner untuk ahli media, dan (e) lembar evaluasi untuk siswa mengevaluasi proses pembelajaran dengan model permainan yang dikembangkan.

\section{Analisis Data}

Analisis data adalah proses mencari dan menyusun secara sistematis data yang diperoleh dari hasil wawancara, catatan lapangan, dan data-data lain, sehingga dapat mudah dipahami, dan temuan tersebut dapat diinformasikan kepada pihak lain. Analisis data dilakukan dengan mengorganisasikan data, menjabarkan ke dalam unit-unit, melakukan sintesa, menyusun ke dalam pola, memilih mana yang penting dan yang akan dipelajari, dan membuat kesimpulan yang dapat disampaikan kepada orang lain (Sugiyono, 2012, p.244). Teknik analisis data dalam penelitian ini adalah uji kelayakan dan keefektifan draf permainan tradisional yang dihasilkan dengan cara penilaian oleh ahli pembelajaran penjas, ahli media, guru dan siswa pada saat uji coba lapangan berlangsung.

Norma kategorisasi yang digunakan sesuai dengan ketentuan Azwar (2003, p. 109) yaitu:

Tabel 1. Pedoman Konversi Nilai

\begin{tabular}{cc}
\hline Formula & Kategori \\
\hline $\mathrm{X}<(\mu-1,0 \sigma)$ & Kurang \\
$(\mu-1,0 \sigma) \leq \mathrm{X}<(\mu+1,0 \sigma)$ & Cukup \\
$(\mu+1,0 \sigma) \leq \mathrm{X}$ & Baik/Efektif \\
\hline
\end{tabular}


Keterangan:

$\mathrm{X}=$ jumlah skor subjek

$\mu=$ mean ideal

$\sigma=$ standar devisiasi ideal

$=1 / 6$ [(jumlah item $\mathrm{x}$ skor tertinggi) -

(jumlah item x skor terendah)]

Uji validitas dan uji reliabilitas Draf model permainan tradisional dilakukan dengan menggunakan data kuesoner untuk responden guru dan siswa pada ujicoba skala kecil maupun skala besar. Uji validitas dan uji reliabilitas dilakukan dengan menggunakan bantuan Microsoft Excell 2007.

\section{Uji Efektifitas Produk Akhir}

Dalam uji efektifitas produk akhir ada dua item yang diujikan antara lain; (a) Karakter (dinilai oleh siswa dan guru), dan (b) Psikomotor sesuai kurikulum SD kelas atas. Pengujian efektifitas dapat dilakukan dengan cara melihat gain ternormalisasinya. Menurut Hake (1999, p. 45) rata-rata gain ternormalisasi didapatkan dari rata-rata posttest dikurangi dengan rata-rata pretest dibagi dengan nilai maksimum dikurangi dengan rata-rata pretest. Jika dibuat dalam persamaan, seperti pada Persamaan 1 berikut ini.

$(\mathrm{g})=\frac{(S f-S i)}{(S \max -S i)}$

Keterangan:

$\langle\mathrm{g}\rangle=$ rata-rata gain ternormalisasi

$\langle\mathrm{Sf}\rangle=$ rata-rata nilai tes akhir (post-test)

$\langle\mathrm{Si}\rangle=$ rata-rata nilai tes awal (pre-test)

Smax $=$ Nilai skor maksimal

Hasil perhitungan diinterpretasikan dengan menggunakan indeks gain $<\mathrm{g}>$, menurut klasifikasi oleh Hake ditunjukkan pada Tabel 2.

Tabel 2. Nilai Indeks Gain Ternormalisasi dan Klasifikasinya

\begin{tabular}{cc}
\hline Indeks Gain Ternormalisasi & Klasifikasi \\
\hline$(\mathrm{g}) \geq 0,70$ & Tinggi \\
$0,30 \leq 0,70$ & Sedang \\
$\leq 0,30$ & Rendah \\
\hline
\end{tabular}

Berdasarkan klasifikasi tersebut, dapat dijelaskan; (a) apabila nilai gain ternormalisasi berada dalam klasifikasi tinggi, maka tingkat efektifitasnya adalah sangat efektif, (b) apabila nilai gain ternormalisasi berada dalam klasifikasi sedang, maka tingkat efektifitasnya adalah efektif, dan (c) apabila nilai gain ternormalisasi berada dalam klasifikasi rendah, maka tingkat efektifitasnya adalah kurang efektif.
Setelah skor siswa dinilai menggunakan rubrik penilaian, selanjutnya adalah menghitung nilai uji praktik, dihitung berdasarkan jumlah skor yang didapatkan dibagi dengan jumlah skor maksimal dan dikalikan dengan 10. Adapun jika dibuat persamaan, dapat dilihat pada Persamaan 2 sebagai berikut.

Nilai Praktik $=\frac{\text { Jumlah skor yang diperoleh }}{\text { Jumlah Skor maksimal }} \times 10$

Penilaian efektifitas pada aspek psikomotor dilakukan dengan cara yang sama dengan penilaian aspek kognitif (karakter), yaitu dengan menghitung besarnya nilai gain ternormalisasi dengan membandingkan nilai pretest dan posttest hasil praktik menggambar siswa. Hasil perhitungan nilai gain lalu diinterpretasikan dengan menggunakan indeks gain $<\mathrm{g}>$, menurut klasifikasi oleh Hake (1999) yang ditunjukan Tabel 2.

\section{HASIL DAN PEMBAHASAN}

Uji coba lapangan pada model permainan tradisional baik skala kecil maupun besar dilaksanakan setelah mendapat validasi atau standar kelayakan dari ahli pembelajaran penjas. Instrumen validasi draf awal model permainan tradisional oleh ahli pembelajaran penjas maupun guru partisipan menggunakan instrumen angket. Adapun hasil dari penilaian validasi para ahli terhadap draf awal permainan tradisional adalah sdapat dilihat Tabel 3 .

Tabel 3. Penilaian Validasi oleh pembelajaran penjas dan guru partisipan

\begin{tabular}{ccccc}
\hline \multirow{2}{*}{ No. } & \multirow{2}{*}{ Permainan } & \multicolumn{3}{c}{ Skor Penilaian } \\
\cline { 3 - 5 } & & A1 & A2 & A3 \\
\hline 1. & Goteng & 77 & 83 & 85 \\
2. & L. Papan & 73 & 79 & 84 \\
3. & Kasti Tangan & 80 & 86 & 87 \\
\hline
\end{tabular}

Tabel 3 menunjukkan penilaian ahli materi terhadap draf awal model permainan tradisional berdasarkan karakter sebagai pembelajaran pendidikan jasmani bagi anak sekolah dasar kelas atas. Total nilai para ahli materi untuk permainan goteng, permainan lari papan/ segi empat, dan permainan kasti tangan semua terletak pada interval $66 \leq \mathrm{X}$. Jadi, penilaian para ahli materi terhadap draf awal model permainan tradisional berdasarkan karakter sebagai pembelajaran pendidikan jasmani bagi anak sekolah dasar kelas atas berkategori baik. 
Jurnal Keolahragaan 5 (2), September 2017 - 190

Puput Widodo, Ria Lumintuarso

Tabel 4. Kategorisasi Penilaian Validasi Ahli Pembelajaran Penjas dan Guru Partisipan

\begin{tabular}{|c|c|c|c|c|c|c|c|c|c|}
\hline \multirow{4}{*}{ Kategori } & \multicolumn{9}{|c|}{ Nama Permainan } \\
\hline & \multicolumn{3}{|c|}{ Goteng } & \multicolumn{3}{|c|}{ Lari Papan/Segi Empat } & \multicolumn{3}{|c|}{ Kasti Tangan } \\
\hline & A1 & $\mathrm{A} 2$ & A3 & A1 & $\mathrm{A} 2$ & A3 & A1 & A2 & A3 \\
\hline & $\mathrm{F}$ & $\mathrm{F}$ & $\mathrm{F}$ & $\mathrm{F}$ & $\mathrm{f}$ & $\mathrm{f}$ & $\mathrm{F}$ & $\mathrm{F}$ & $\mathrm{F}$ \\
\hline Kurang & - & - & - & - & - & - & - & - & - \\
\hline Cukup & - & - & - & - & - & - & - & - & - \\
\hline Baik & 77 & 83 & 85 & 73 & 79 & 84 & 80 & 86 & 87 \\
\hline
\end{tabular}

Berdasarkan penilaian para ahli materi terhadap angket validasi, terlihat bahwa total nilai draf awal model permainan tradisional telah memenuhi persyaratan kelayakan untuk diujicobakan di lapangan. Penghitungan ini menjadi dasar bahwa draf model permainan tradisional sebagai pembelajaran pendidikan jasmani untuk membangun karakter bagi anak sekolah dasar kelas atas adalah layak untuk dilakukan uji coba skala kecil.

\section{Uji Coba Skala Kecil}

Uji coba skala kecil dilakukan pada anak kelas atas SD Negeri Aditirto, Pejagoan, Kebumen dengan jumlah 30 anak. Pelaksanaan uji coba skala kecil direkam dalam $D V D$ kemudian diobservasi oleh observer (ahli pembelajaran pendidikan jasmani, ahli media dan guru penjasorkes sekolah dasar). Data yang diperoleh dari observer berupa: (1) data hasil observasi penilaian karakter permainan tradisional, (2) data hasil observasi pengembangan tradisional, (4) data hasil observasi keefektifan model permainan tradisional, (5) data hasil penilian observasi ahli media, (6) data hasil evaluasi siswa dan (7) saran perbaikan. Data uji coba dengan skala kecil model permainan tradisional terdiri dari 3 jenis permainan yang bertujuan untuk membangun karakter (kerja sama, kejujuran, percayadiri, dan peduli sesama) pada siswa SD kelas atas. Adapun hasil uji coba skala kecil adalah sebagai berikut:

Tabel 5. Hasil Uji Coba Skala Kecil

\begin{tabular}{ccc}
\hline No. & Penilaian & Kategori \\
\hline 1. & Guru Partisipan & Baik \\
2. & Ahli Media & Baik \\
3. & Siswa & Baik \\
\hline
\end{tabular}

Berdasarkan kategori penilaian semua item hasil uji coba skala kecil berkategori baik. Hasil penilaian karakter pada uji coba skala kecil terhadap pengembangan model permainan tradisional untuk membangun karakter disajikan sebagai berikut:

Tabel 6. Hasil Uji Coba Karakter Skala Kecil

\begin{tabular}{cccl}
\hline Penilaian & TM & M & SM \\
\hline Guru Partisipan & 3 & 10 & 13 \\
\hline Hasil penilaian &
\end{tabular}

Hasil penilaian karakter pada guru penjas pada uji coba skala kecil terhadap pengembangan model permainan tradisional mendapat total nilai TM: 3, M: 14, SM: 13 poin dengan presentase TM: 10\%, M: 46,7\%, dan SM: 43,3\%. Berdasarkan penilaian guru penjas, terlihat bahwa total penilaian karakter dapat dikatakan baik dengan katagori memenuhi $46 \%$ dan sangat memenuhi $43,3 \%$.

\section{Uji Coba Skala Besar}

Proses revisi terhadap draf model permainan tradisional yang diujicobakan pada skala kecil ditindaklanjuti dengan melakukan uji coba lapangan skala besar. Uji coba skala besar dilaksanakan di 5 (lima) sekolah yaitu SDN 1 Karangpoh dengan jumlah siswa 28, SDN 1 Logede dengan jumlah siswa 26, SDN 4 Pejagoan dengan jumlah 22 siswa, SDN 1 Kebulusan dengan jumlah siswa 24, dan SDN 3 Kebulusan dengan jumlah siswa 30. Pelaksanaan uji coba skala besar direkam dalam DVD kemudian diobservasi oleh observer (ahli pembelajaran pendidikan jasmani, guru penjasorkes $\mathrm{SD}$, dan ahli media). Data yang diperoleh dari observer berupa: (1) data hasil observasi penilaian karakter permainan tradisional, (2) data hasil observasi pengembangan tradisional (untuk guru dan siswa), (3) data hasil observasi keefektifan model permainan tradisional, (4) data hasil penilian observasi ahli media, (5) data hasil evaluasi siswa dan (6) saran perbaikan.

Tabel 7. Hasil Uji Coba Skala Besar

\begin{tabular}{ccc}
\hline No & Penilaian & Kategori \\
\hline 1 & Guru Partisipan & Baik \\
2 & Ahli Media & Baik \\
3 & Siswa & Baik \\
\hline
\end{tabular}

Berdasarkan kategori penilaian semua item hasil uji coba skala besar berkategori baik. Hasil penilaian karakter pada uji coba skala besar terhadap pengembangan model permainan 
tradisional untuk membangun karakter disajikan Tabel 8 .

Tabel 8. Hasil Uji Coba Karakter Skala Besar

\begin{tabular}{cccc}
\hline Penilaian & TM & M & SM \\
\hline Guru Partisipan & 0 & 74 & 136 \\
\hline
\end{tabular}

Hasil penilaian karakter pada ahli materi dan guru penjas pada uji coba skala besar terhadap pengembangan model permainan tradisional mendapat total nilai TM: 0, M: 74, SM: 136 poin dengan presentase TM: $\mathbf{0 \%}, \mathrm{M}: \mathbf{3 5 , 2 \%}$, dan SM: 64,8\%. Jadi dapat di simpul-kan bahwa model permainan tradisional dapat membangun karakter (kerja sama, kejujuran, percayadiri, dan peduli sesama) dengan hasil sebagian besar sangat baik/memenuhi kriteria yang diinginkan.

\section{Uji Efektifitas}

Selanjutnya model permainan tradisional yang diujicobakan pada skala besar ditindaklanjuti dengan melakukan uji efektifitas. Uji efektifitas dilaksanakan di SDN Aditirto dengan jumlah siswa 30 dengan 6 kali perlakuan. Pelaksanaan uji efektifitas dilakukan dengan menguji dua kategori yaitu karakter dan psikomotor yang terdapat pada KD kurikulum SD. Adapun hasilnya pada Tabel 9 .

Tabel 9. Hasil Uji Efektivitas Produk

\begin{tabular}{cclcc}
\hline No. & $\begin{array}{c}\text { Uji } \\
\text { Efektifitas }\end{array}$ & Penilaian & $\begin{array}{c}\text { Hasil } \\
\text { Pretest }\end{array}$ & $\begin{array}{c}\text { Hasil } \\
\text { Postest }\end{array}$ \\
\hline 1. & Karakter & Siswa & 602 & 712 \\
& & Guru & 202 & 245 \\
2. & Psikomotor & Guru & 209,5 & 250 \\
\hline
\end{tabular}

Data Persamaan 1 siswa

Data tersebut kemudian dimasukan ke dalam tabel gain ternormalisasi dengan rumus persamaan 1 sebagai berikut:

$(\mathrm{g})=\frac{(S f-S i)}{(S \max -S i)}$

Keterangan:

$\langle\mathrm{g}\rangle=$ rata-rata gain ternormalisasi

$\langle\mathrm{Sf}\rangle=$ rata-rata nilai tes akhir (post-test)

$\langle\mathrm{Si}\rangle=$ rata-rata nilai tes awal (pre-test)

Smax $=$ Nilai skor maksimal

$\begin{aligned}(\mathrm{g}) & =\frac{(23,7-20,1)}{(32-20,1)} \\ & =0,302\end{aligned}$

Hasil per perhitungan diinterpretasikan dengan menggunakan indeks gain $<\mathrm{g}>$, menurut klasifikasi oleh Hake ditunjukkan pada Tabel 10.
Tabel 10. Nilai Indeks Gain Ternormalisasi dan Klasifikasinya

\begin{tabular}{cc}
\hline Indeks Gain Ternormalisasi & Klasifikasi \\
\hline$(\mathrm{g}) \geq 0,70$ & Tinggi \\
$0,30 \leq 0,70$ & Sedang \\
$\leq 0,30$ & Rendah \\
\hline
\end{tabular}

Dengan melihat hasil perhitungan dengan melihat tabel Indek gain maka dapat disimpulkan bahwa hasil uji efektifitas pengembangan nilai karakter pada pengembangan model permainan tradisional mendapatkan nilai 0,302 terletak pada interval $0,30 \leq 0,70$ dengan klasifikasi sedang, dengan kata lain uji efektivitas dikatakan efektif.

Data Persamaan 1 guru

Data di atas kemudian dimasukan ke dalam tabel gain ternormalisasi dengan rumus persamaan 1 sebagai berikut:

$(\mathrm{g})=\frac{(S f-S i)}{(S \operatorname{smax}-S i)}$

Tabel 11. Nilai Indeks Gain Ternormalisasi dan Klasifikasinya

\begin{tabular}{cc}
\hline Indeks Gain Ternormalisasi & Klasifikasi \\
\hline$(\mathrm{g}) \geq 0,70$ & Tinggi \\
$0,30 \leq 0,70$ & Sedang \\
$\leq 0,30$ & Rendah \\
\hline
\end{tabular}

Keterangan:

$\langle\mathrm{g}\rangle=$ rata-rata gain ternormalisasi

$\langle\mathrm{Sf}\rangle=$ rata-rata nilai tes akhir (post-test)

$\langle\mathrm{Si}\rangle=$ rata-rata nilai tes awal (pre-test)

Smax $=$ Nilai skor maksimal

$(\mathrm{g})=\frac{(8,67-6,67)}{(10-6,67)}$

$=0,45$

Hasil per Hasil perhitungan diinterpretasikan dengan menggunakan indeks gain $<\mathrm{g}>$, menurut klasifikasi oleh Hake ditunjukkan pada Tabel 12.

Tabel 12. Nilai Indeks Gain Ternormalisasi dan Klasifikasinya

\begin{tabular}{cc}
\hline Indeks Gain Ternormalisasi & Klasifikasi \\
\hline$(\mathrm{g}) \geq 0,70$ & Tinggi \\
$0,30 \leq 0,70$ & Sedang \\
$\leq 0,30$ & Rendah \\
\hline
\end{tabular}

Dengan melihat hasil perhitungan dengan melihat tabel Indek gain maka dapat disimpulkan bahwa hasil uji efektifitas pengembangan nilai karakter pada pengembangan model permainan tradisional mendapatkan nilai 0,45 terletak pada interval $0,30 \leq 0,70$ dengan klasifikasi sedang, dengan kata lain uji efektivitas dikatakan efektif. 
Berdasarkan uji validitas dan reliabilitas menggunakan bantuan Microsoft Excell 2007, diperoleh hasil sebagai berikut; (a) uji validitas dan reliabilitas instrumen karakter dapat diketahui bahwa seluruh item memiliki nilai korelasi $r$ lebih besar dari $r$ tabel $(0,514)$. Dengan demiikian dapat disimpulkan bahwa item 1 sampai dengan 10 dapat dikatakan valid. Dan dapat diketahui bahwa nilai Cronbach's Alpha diperoleh sebesar 0,914. Nilai tersebut $>0,6$. Dengan demiikian dapat disimpulkan bahwa item 1 sampai dengan 10 dapat dikatakan reliabel, (b) uji validitas dan reliabilitas instrumen guru, dapat diketahui bahwa seluruh item memiliki nilai korelasi $r$ lebih besar dari $r$ tabel $(0,878)$. Dengan demiikian dapat disimpulkan bahwa item 1 sampai dengan 22 dapat dikatakan valid, dan dapat diketahui bahwa nilai Cronbach's Alpha diperoleh sebesar 1,00. Nilai tersebut $>$ 0,6 . Dengan demiikian dapat disimpulkan bahwa item 1 sampai dengan 22 dapat dikatakan reliabel, dan (c) uji validitas dan reliabilitas instrumen siswa, dapat diketahui bahwa seluruh item memiliki nilai korelasi $\mathrm{r}$ lebih besar dari $\mathrm{r}$ tabel $(0,173)$. Dengan demiikian dapat disimpulkan bahwa item 1 sampai dengan 16 dapat dikatakan valid, dan dapat diketahui bahwa nilai Cronbach's Alpha diperoleh sebesar 0,614. Nilai tersebut $>0,6$. Dengan demiikian dapat disimpulkan bahwa item 1 sampai dengan 16 dapat dikatakan reliabel.

\section{SIMPULAN}

Produk akhir penelitian ini menghasilkan buku pedoman peraturan dan DVD pembelajaran model permainan tradisional untuk membangun karakter (kerja sama, kejujuran, percaya diri, dan peduli sesama) pada siswa SD kelas atas. Hasil semua penelitian berdasarkan perhitungan normatif berkategori baik, berkategori baik artinya model yang dikembangkan dapat mengembangkan karakter siswa, dan model yang dikembangkan sesuai dengan karakteristik dan pembelajaran penjas. Model yang digunakan juga mudah digunakan guru dalam pembelajaran penjas. Uji Efektifitas dengan melihat tabel gain semua penilaian berkatagori sedang, data dalam uji efektifitas berdistribusi normal dan uji t pretest dan postest mengalami perubahan yang signifikan.

\section{DAFTAR PUSTAKA}

Ardiwinata, A. A. (2006). Olahraga tradisional: Kumpulan permainan rakyat. Jakarta: Cerdas Jaya.
Azwar, S. (2003). Penyusunan skala psikologi. Yogyakarta : Pustaka Pelajar . https://doi.org/2003

Dharmamulja, S. (1992). Transformasi nilai melalui permainan rakyat Daerah Istimewa Yogyakarta. Departemen Pendidikan dan Kebudayaan, Direktorat Jenderal Kebudayaan, Direktorat Sejarah dan Nilai Tradisional, Proyek Penelitian, Pengkajian dan Pembinaan Nilai-Nilai Budaya.

Gall, M. D., Gall, J. P., \& Borg, W. R. (2007). Educational research: An introduction. Boston: Pearson/Allyn \& Bacon.

Hake, R. R. (1999). Analyzing change/Gain scores. Retrieved from http://www.physics.indiana.edu/ sdi/ AnalyzingChange-Gain.pdf

Husna M, A. (2009). 100+ permainan tradisional Indonesia untuk kreativitas, ketangkasan, dan keakraban: sesuai untuk edukasi, training, dan outbound. Yogyakarta: Andi.

Isti Dwi P.W \& Touvan J.S. (2013). Pendidikan karakter melalui pendidikan jasmani. Bandung: CV. Bintang WarliArtika.

Kesuma, D. (2011). Pendidikan Karakter. Bandung: PT Remaja Rosdakarya.

Linggar, S. (2010). Ayo lestarikan permainan tradisional. Jakarta: CV Karya Mandiri Nusantara.

Lusiana, E. (2012, October 31). Membangun pemahaman karakter kejujuran melalui permainan tradisional jawa pada anak usia dini di Kota Pati. Universitas Negeri Semarang. Retrieved from http://lib.unnes.ac.id/18700/

Misbach, I. H. (2006). Peran permainan tradisional yang bermuatan edukatif dalam menyumbang pembentukan karakter dan identitas bangsa. Laporan Penelitian.

Purwaningsih, E. (2006). Permainan tradisional anak: Salah satu khasanah budaya yang perlu dilestarikan. 
Sejarah Dan Budaya Jawa, 40.

Rich, D. (2008). Megaskills. Houghton Mifflin Co.

Sridadi, S. (2009). Modifikasi permainan softball untuk siswa sekolah. Jurnal Pendidikan Jasmani Indonesia, 6(1). Retrieved from https://journal.uny.ac.id/index.php/jpji /article/view/425

Sugiyono. (2010). Metode penelitian kuantitatif kualitatif dan $R \& D$.
Bandung: Alfabeta.

Suharjana, F. (2011). Pengembangan pembelajaran senam melalui bermain di sekolah dasar. Jurnal Pendidikan Jasmani Indonesia, 8(1). Retrieved from https://journal.uny.ac.id/index.php/jpji /article/view/3479

Sujiono, Y. N., \& Sujiono, B. (2010). Bermain kreatif berbasis kecerdasan jamak. Jakarta: Indeks. 